\title{
MODAL INTELEKTUAL, KEUNGGULAN KOMPETITIF, DAN KINERJA KEUANGAN PADA PERUSAHAAN HIGH-IC DI INDONESIA DAN SINGAPURA
}

\section{Indah Yuliana ${ }^{1}$, Jam'iyyatul Khoiriyah ${ }^{2}$}

${ }^{1}$ Fakultas Ekonomi Universitas Islam Negeri Maulana Malik Ibrahim Malang

Email : indahoty@manajemen.uin-malang.ac.id

\begin{tabular}{|c|c|}
\hline ARTICLE INFO & ABSTRACT \\
\hline $\begin{array}{l}\text { Kata Kunci: } \\
\text { Modal Intelektual, Kinerja Keuangan, } \\
\text { Keunggulan Kompetitif } \\
\text { Keywords : } \\
\text { Intellectual Capital, Financial Performance, } \\
\text { Competitive Advantage } \\
\text { How to cite: } \\
\text { Yuliana, Indah., Khoiriyah, Jam'iyyatul } \\
\text { (2018). Modal Intelektual, Keunggulan } \\
\text { Kompetitif, dan Kinerja Keuangan Pada } \\
\text { Perusahaan High Ic di Indonesia dan } \\
\text { Singapura. JMM UNRAM, 7(4), } 17 \text { - } 32 \\
\text { DoI: } \\
\text { 10.29303/jmm.v7i4.343 }\end{array}$ & $\begin{array}{l}\text { This study aims to examine the effect of Intellectual Capital } \\
\text { on Competitive Advantage, the effect of Intellectual Capital } \\
\text { on Corporate Financial Performance, and the effect of } \\
\text { Intellectual Capital on Corporate Financial Performance } \\
\text { through Competitive Advantage (Competitive Advantage) } \\
\text { by using a quantitative descriptive approach. The population } \\
\text { of this study was the financial statements of the Indonesia } \\
\text { Stock Exchange and the Singapore Stock Exchange and was } \\
\text { selected by purposive sampling, namely } 33 \text { companies from } \\
\text { LQ45 in Indonesia and } 26 \text { companies from the Straits Times } \\
\text { Index in Singapore in 2014-2016. The data processing of } \\
\text { this study uses path analysis (path analysis) and classic } \\
\text { assumption test to measure the influence of variables on the } \\
\text { financial performance of companies in Indonesia and in } \\
\text { Singapore. The results showed that there was a positive and } \\
\text { significant effect of Intellectual Capital on Competitive } \\
\text { Advantage, Intellectual Capital on Financial Performance, } \\
\text { and Competitive Advantage able to mediate the effect of } \\
\text { Intellectual Capital on Financial Performance in 2014-2016. } \\
\text { Penelitian ini bertujuan untuk menguji pengaruh Modal } \\
\text { Intelektual (Intellectual Capital) terhadap Keunggulan } \\
\text { Kompetitif Perusahaan (Competitive Advantage), pengaruh } \\
\text { Modal Intelektual (Intellectual Capital) terhadap Kinerja } \\
\text { Keuangan Perusahaan, dan pengaruh Modal Intelektual } \\
\text { (Intellectual Capital) terhadap Kinerja Keuangan } \\
\text { Perusahaan melalui Keunggulan Kompetitif (Competitive } \\
\text { Advantage) dengan menggunakan pendekatan kuantitatif } \\
\text { deskriptif. Populasi penelitian ini adalah data laporan } \\
\text { keuangan Bursa Efek Indonesia dan Bursa Efek Singapura } \\
\text { dan terpilih sampel melalui purposive sampling yaitu } 33 \\
\text { perusahaan dari LQ45 di Indonesia dan } 26 \text { perusahaan dari } \\
\text { Strait Times Index di Singapura pada tahun 2014-2016. } \\
\text { Pengolahan data penelitian ini menggunakan analisis jalur } \\
\text { (path analysis) dan uji asumsi klasik untuk mengukur }\end{array}$ \\
\hline
\end{tabular}




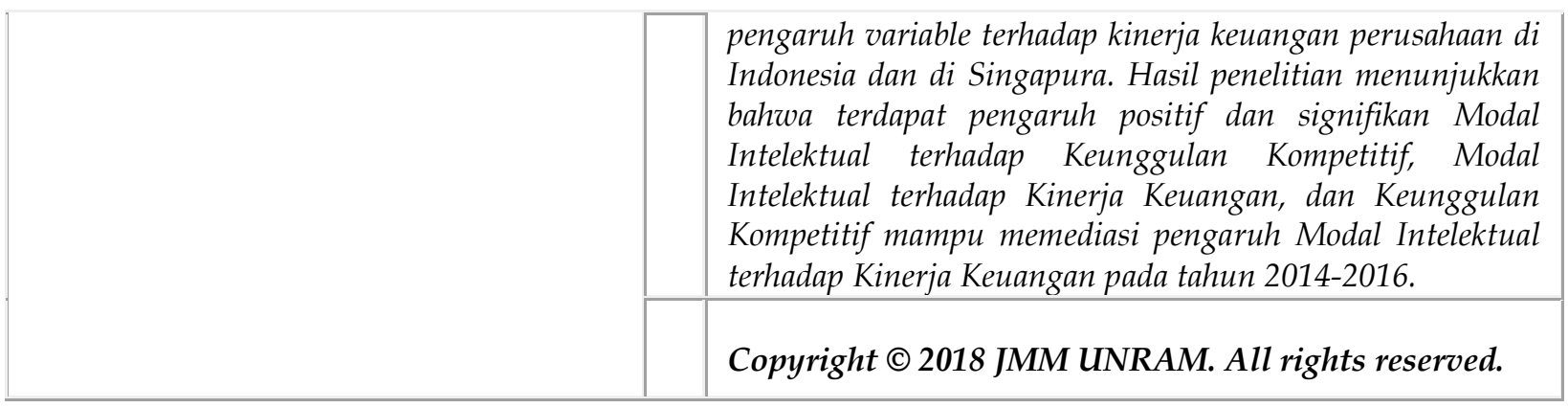

\section{PENDAHULUAN}

Persaingan pasar yang tak terbatas memberikan implikasi perusahaan harus memanfaatkan kreatifitas dan kinerjanya untuk menciptakan nilai tambah bagi perusahaan dengan sumber daya yang terbatas. Susanto (2014:203) mengemukakan telah terjadi transformasi terhadap human capital, dimana manusia dianggap sebagai engine dalam proses transformasi karyawan, bukan sebagai cost, namun sebagai human capital yang memberikan nilai tambah pada perusahaan dengan indikator keberhasilannya adalah efisiensi biaya, adanya inovasi, dan value creation sebagai bentuk investasi. Pulic (2000) menjelaskan bahwa sumber daya manusia dan kemampuan mereka dalam menciptakan efisiensi nilai tambah merupakan bagian dari modal intelektual. Fakta ini semakin meyakinkan bahwa peningkatan efeisiensi nilai tambah (value added) yang dihasilkan oleh modal intelektual sangat berpengaruh terhadap kinerja keuangan perusahaan. Aspek kompetitif yang menjadi pembeda perusahaan dengan saingannya adalah intelektualitas, ilmu pengetahuan yang dimiliki, pengelolaan informasi, hak paten intelektual, dan pengalaman yang dapat digunakan untuk menciptakan kesejahteraan perusahaan (Stewart,1997:2). Riaupos (2016) menjelaskan bahwa modal intelektual merupakan salah satu solusi atas perlambatan ekonomi global, karena aspek pendanaan (financial capital) sebagai penunjang peningkatan bisnis tidak dapat diandalkan lagi dan sudah jelas bahwa para pemilik modal tidak akan mau menambah modalnya pada bisnis apapun dalam kondisi perekonomian yang sulit. Modal intelektual dianggap patut menjadi andalan utama bagi perusahaan yang ingin keluar dari krisis yang multidimensi ini. Modal kecerdasan dan kejelian dari manusia-manusia yang ada di dalam suatu perusahaan akan jauh lebih bernilai dalam meningkatan kapitalisasi atas nilai perusahaan dibandingkan dengan hanya menggantungkan diri kepada kekuatan modal dan kecanggihan dari sistem maupun teknologi yang mumpuni sekalipun.

Selain meningkatkan kinerja keuangan perusahaan, modal intelektual juga dapat meningkatkan keunggulan kompetitif atau kemampuan perusahaan yang sulit ditiru oleh perusahaan saingan, Resource Based Theory memandang setiap perusahaan memiliki kumpulan sumber daya dan kemampuan yang berbeda yang disebutkan Susanto (2014: 8384), bahwa konsep inti resource based theory untuk mencari dan mengidentifikasi karakteristik sumber daya yang dapat dipergunakan untuk memelihara keunggulan bersaing dengan cara mengembangkan keterampilan, sumber daya, dan proses pengelolaan yang dapat meningkatkan nilai (value) bagi pelanggan. Setiap perusahaan memiliki kumpulan sumber daya dan kemampuan yang berbeda. Perbedaan tersebut akan memberikan keunggulan kompetitif bagi perusahaan tertentu. Perusahaan dapat bersaing dengan perusahaan lain untuk mendapatkan keunggulan kompetitif dalam mengelola sumber daya yang dimilikinya sesuai dengan kemampuan perusahaan. Dengan pengelolaan yang baik dan maksimal atas seluruh potensi inilah organisasi dapat menciptakan value added untuk kemudian mendorong kinerja keuangan perusahaan 
sebagai bentuk intervensi stakeholder dalam manajemen. Beberapa hasil penelitian menunjukkan bahwa modal intelektual berpengaruh terhadap kinerja keuangan (Tewal (2008), Lestari (2012), Poetri (2013), Tambun (2014), Daud (2016), Indah (2017), Garanina, 2017). Hasil penelitian Sudiarditha (2005) dan Hartati (2014), menunjukkan bahwa modal intelektual berpengaruh positif dan signifikan terhadap keunggulan kompetitif. Selain itu, Widyaningdyah (2013) menyatakan bahwa perusahaan yang dapat mempertahankan keunggulan kompetitifnya mempunyai kemampuan dalam menciptakan nilai tambah bagi perusahaan. Hasil penelitian Tewal (2008) dan Tambun (2014), menjelaskan bahwa terdapat pengaruh positif dan signifikan keunggulan bersaing terhadap kinerja keuangan perusahaan.

Pertumbuhan nilai ekspor nasional Indonesia selama ini, bertumpu pada produkproduk berbasis sumber daya alam, yaitu ekspor produk non-migas yang masih dalam bentuk bahan baku, misalnya karet, kopi, dan kakao (Kemendag, 2015). Modal intelektual menjadi salah satu persoalan besar yang dihadapi oleh Indonesia saat ini. Centre of Knowledge for Business Competitiveness (CK4BC, 2015) menyatakan bahwa perekonomian Indonesia dibandingkan dengan Singapura sangat tertinggal jauh. Sekitar $80 \%$ GDP Negara Singapura disumbangkan oleh kontribusi modal manusia, bukan oleh kekayaan sumber daya alam. Menurut hasil studi yang dilakukan oleh Pricewaterhouse Coopers (PwC), Strait Times Index (STI) menunjukkan ada peningkatan kemudahan melakukan usaha atau ease of doing business, demografi, dan kesiapan teknologi di Singapura. Dengan minimnya kekayaan alam yang dimilikinya Singapura terus berusaha meningkatkan modal intelektual dan keunggulan kompetitifnya dalam persaingan di internasional. Dari latar belakang tujuan penelitian : (1) menganalisis pengaruh modal intelektual terhadap keunggulan kompetitif dan kinerja keuangan (2) menganalisis pengaruh keunggulan kompetitif terhadap kinerja keuangan perusahaan (3) menganalisis pengaruh variabel keunggulan kompetitif sebagai mediasi antara hubungan modal intelektual terhadap kinerja keuangan.

\subsection{Resource Based Theory}

Susanto (2014: 83-84), menyebutkan bahwa konsep inti resource based theory adalah untuk mencari dan mengidentifikasi karakteristik sumber daya yang dapat dipergunakan untuk memelihara keunggulan bersaing dengan cara mengembangkan keterampilan, sumber daya, dan proses pengelolaan yang dapat meningkatkan nilai (value) bagi pelanggan. Keunggulan kompetitif merupakan hal apapun yang dilakukan perusahaan agar dipandang lebih baik daripada perusahaan saingan (David,2011:9). Pendekatan berbasis sumber daya (resource-based view of the firm theory), muncul karena adanya pertanyaan mengenai mengapa sebuah perusahaan dapat mengungguli perusahaan lain dan mempunyai kinerja superior yang berkelanjutan (Barney dan Clark; 2007). Kumpulan sumber daya yang unik yang dimiliki dan dikendalikan perusahaan memungkinkan perusahaan untuk mencapai dan mempertahankan kinerja superior yang berkelanjutan. Sumber daya unik yang dimaksudkan adalah sumber daya yang bernilai (valuable), langka (rare), tidak dapat ditiru (inimitable), dan tidak tergantikan (non-subtitutable). Jenis sumber daya ini dapat mengantarkan perusahaan pada pencapaian keunggulan kompetitif.

\subsection{Modal Intelektual}

Modal intelektual merupakan kumpulan manusia dalam perusahaan yang dapat memberikan aspek kompetitif perusahaan dalam posisi pasar. Aspek kompetitif yang menjadi pembeda perusahaan dengan saingannya adalah intelektualitas, ilmu pengetahuan yang dimiliki, pengelolaan informasi, hak paten intelektual, dan pengalaman yang dapat digunakan untuk menciptakan kesejahteraan perusahaan. Menurut 
International Federation of Accountants (IFAC,1998), modal intelektual (intellectual capital) adalah sinonim dengan kekayaan intelektual (intellectual property), asset intelektual (intellectual asset), dan asset pengetahuan (knowledge asset). Modal ini dapat diartikan sebagai modal yang berbasis pada pengetahuan yang dimiliki perusahaan. Lebih lanjut IFAC mengestimasikan bahwa dewasa ini, 50-90 persen nilai perusahaan ditentukan oleh manajemen atas modal intelektual (intellectual capital) bukan manajemen atas asset tetap. Modal intelektual merupakan pengetahuan, informasi, pengaplikasian pengalaman, proses dalam industry perusahaan, dan teknologi relasi pelanggan dan kemampuan profesional yang bernilai asset bagi perusahaan. Modal Intelektual memandang pengetahuan sebagai sebuah kelangkaan dan sulit untuk ditransfer dan ditirukan yang lain, yang merupakan sebuah sumber daya penting untuk mencapai keunggulan kompetitif dalam menghadapi persaingan. Kemampuan dan keefektifan perusahaan dalam menciptakan, mengolah, sharing, dan penyampaian pengetahuan dan informasi menentukan nilai yang diperoleh perusahaan sebagai dasar penilaian keunggulan kompetitif perusahaan berkelanjutan dalam jangka panjang.

\subsection{Keunggulan Kompetitif}

Keunggulan kompetitif adalah jantung dari kinerja perusahaan dalam pasar yang kompetitif. Hal ini mengenai bagaimana sebuah perusahaan benar-benar menempatkan strategi generik ke dalam praktik (Porter, 1985:xv). Keunggulan kompetitif bertumbuh secara fundamental dari nilai yang memungkinkan perusahaan untuk menciptakan nilai bagi para pembelinya melebihi biaya yang dikeluarkan perusahaan untuk menciptakannya (Porter, 1985:3). Menurut David (2011:9), keunggulan kompetitif merupakan hal apapun yang dapat dilakukan perusahaan sehingga lebih baik dibandingkan dengan perusahaan saingan. Susanto (2014:88) menyebutkan bahwa sumber utama keunggulan kompetitif berasal dari kombinasi efektif antara lingkungan nasional perusahaan dan strategi perusahaan itu sendiri. Kondisi dalam suatu Negara dapat menjadikan lingkungan yang kondusif sehingga perusahaan dapat memperoleh keunggulan dalam bersaing, namun tetap bergantung pada bagaimana perusahaan memanfaatkan situasi tersebut. Widyaningdyah dan Aryani (2013), menjelaskan bahwa sebuah perusahaan dikatakan mempunyai keunggulan kompetitif apabila dapat menciptakan nilai ekonomis yang lebih tinggi dibandingkan perusahaan lain dalam industrinya. Sedangkan menurut Dessler (2001:81) merupakan semua faktor yang mungkin dimiliki organisasi untuk mendiferensiasikan produk atau jasa dari produk dan jasa pesaing untuk meningkatkan presentase pasar. Namun lebih lanjut dikatakan hal yang paling penting adalah menjaga keberlanjutan dari keunggulan kompetitif tersebut atau yang biasa disebut sebagai sustained competitive advantage (Barney and Clark, 2007).

\subsection{Economic Value Added (EVA)}

Brigham dan Houston (2010:111-112) menyebutkan bahwa pengukuran kinerja keuangan menggunakan EVA merupakan estimasi laba ekonomi yang sebenarnya untuk tahun tertentu, dan sangat jauh berbeda dari laba bersih akuntansi dimana laba akuntansi tidak dikurangi dengan biaya ekuitas, sementara dalam perhitungan EVA biaya ekuitas ini akan dikeluarkan. Jika nilai EVA positif, maka laba operasi setelah pajak akan melebihi biaya modal yang dibutuhkan dan tindakan manajemen menambah nilai bagi pemegang saham berguna sebagai panduan untuk menghitung kompensasi yang wajar bagi manajer divisi sampai manajer puncak perusahaan. Penerapan Economic Value Addded (EVA) untuk menghitung kinerja keuangan dalam suatu perusahaan akan lebih memfokuskan perhatian pada penciptaan nilai perusahaan, hal ini merupakan salah satu keunggulan Economic Value Added. Hal utama yang membedakan EVA dengan tolak ukur keuangan yang lain 


\section{NATIONALLY ACCREDITED JOURNAL - DECREE NO. 21/E/KPT/2018}

yakni, EVA tidak dibatasi oleh akuntansi berlaku umum. EVA dapat mendukung setiap keputusan dalam sebuah perusahaan mulai dari investasi modal, kompensasi karyawan dan kinerja unit bisnis. Struktur EVA yang sederhana membuatnya bisa digunakan oleh bagian engineering, enviromental, dan bagian lainnya sebagai alat yang umum digunakan untuk mengomunikasikan aspek yang berbeda dari kinerja keuangan (Poetri, 2013).

\subsection{Hipotesis}

H1 : Modal Intelektual (intellectual capital) berpengaruh signifikan terhadap Keunggulan kompetitif perusahaan.

H2 : Modal Intelektual (intellectual capital) berpengaruh signifikan terhadap Kinerja keuangan Perusahaan.

H3 : Terdapat pengaruh signifikan antara Modal Intelektual (Intellectual Capital) terhadap Kinerja Keuangan Perusahaan melalui Keunggulan Kompetitif (Competitive Advantage).

\section{METODE PENELITIAN}

Jenis penelitian ini adalah kuantitatif dengan pendekatan deskriptif. Populasi dalam penelitian ini adalah seluruh perusahaan di Indonesia yang termasuk dalam Indeks LQ45 yang berjumlah 33 perusahaan dan perusahaan yang tergabung dalam Strait Times Index berjumlah 26 perusahaan. Tehnik pengambilan sampel menggunakan metode purposive sampling. Jenis data yang digunakan dalam penelitian ini adalah data sekunder dan teknik pengumpulan data dengan dokumentasi.

Teknik Pengambilan Sampel di LQ45 dan Strait Times Index Tahun 2014-2016

\begin{tabular}{|l|c|c|}
\hline \multicolumn{1}{|c|}{ Keterangan } & Indeks LQ45 & Strait Times Index \\
\hline Perusahaan yang tercatat pada tahun 2014-2016 & 52 perusahaan & 34 perusahaan \\
\hline $\begin{array}{l}\text { Perusahaan yang tidak tercatat secara terus } \\
\text { menerus pada tahun 2014-2016 }\end{array}$ & (19 perusahaan) & (8 perusahaan) \\
\hline Jumlah sampel & $\mathbf{3 3}$ perusahaan & 26 perusahaan \\
\hline
\end{tabular}

\subsection{Variabel Bebas (Modal Intelektual)}

Variabel Bebas dalam penelitian ini adalah Modal Intelektual yang diukur dengan metode Value Added Intellectual Capital (VAICTM) yang dikembangkan oleh penelitian Pulic pada tahun 2000 yang digunakan untuk menyediakan informasi tentang value creation efficiency dari aset berwujud (tangible asset) dan aset tidak berwujud (intangible asset) yang dimiliki perusahaan. Pendekatan VAICTM ini relatif mudah dan sangat mungkin untuk dilakukan, karena dikonstruksi dari akun-akun dalam laporan keuangan perusahaan (Ulum, 2009:86-87). Tahapan formulasi perhitungan VAICTM (Pulic, 2000):

Tahap Pertama: Menghitung Value Added (VA)

Model ini dimulai dengan kemampuan perusahaan untuk menciptakan value added (VA). VA adalah indicator paling objektif untuk menilai kinerja dan keberhasilan bisnis serta menunjukkan kemampuan perusahaan dalam penciptaan nilai (value creation). VA dihitung sebagai selisih antara output dan input seperti berikut:

$$
\text { VA = OUT - IN atau VA = OP + EC + D + A }
$$

Keterangan:

OUT = output : total penjualan dan pendapatan lain

IN = input : beban penjualan dan biaya-biaya lain (selain beban karyawan)

OP = laba operasi atau operating profit 


\section{NATIONALLY ACCREDITED JOURNAL - DECREE NO. 21/E/KPT/2018}

EC = beban karyawan atau employee cost

$\mathrm{D} \quad=$ depresiasi atau depreciation

A $\quad=$ amortisasi atau amortisation

Tahap Kedua: Menghitung Value Added Capital Employed (VACA)

VACA merupakan indikator VA dalam menciptakan satu unit dari physical capital (kontribusi satu unit yang dibuat oleh tenaga kerja (CE) terhadap penciptaan nilai (VA) perusahaan).

Keterangan :

$$
\mathrm{VACA}=\mathrm{VA} / \mathrm{CE}
$$

$\mathrm{VA}=$ Value Added

$\mathrm{CE}=$ Capital Employed: book value of the net asset for a company (Pulic, 2008)

\section{Tahap Ketiga: Menghitung Value Added Human Capital (VAHU)}

VAHU merupakan hubungan antara VA dan Human Capital (HC) yang menunjukkan bahwa berapa banyak VA dapat dihasilkan dengan dana yang dikeluarkan untuk tenaga kerja. Hubungan ini mengindikasikan kemampuan HC untuk menciptakan nilai dalam perusahaan. Rasio ini menunjukkan kontribusi yang dibuat oleh setiap rupiah yang diinvestasikan dalam HC terhadap VA organisasi. Pulic berargumen bahwa total salary and wage costs adalah indicator dari HC perusahaan.

Keterangan:

$$
\text { VAHU }=\text { VA } / \text { HC }
$$

$\mathrm{VA}=$ Value Added

$\mathrm{HC}=$ Human Capital $:$ beban karyawan

\section{Tahap Keempat : Menghitung Structural Capital Value Added (STVA)}

Pulic (2000) menguraikan STVA sebagai koefisien yang menunjukkan kontribusi structural capital (SC) dalam penciptaan nilai (VA). STVA mengukur berapa jumlah SC yang dibutuhkan untuk menghasilkan 1 Rupiah dari VA dan merupakan indikasi bagaimana keberhasilan SC dalam penciptaan nilai. SC bukanlah ukuran yang independen sebagaimana $\mathrm{HC}$, ia dependen terhadap value creation. Artinya semakin besar kontribusi $\mathrm{HC}$ dalam value creation, makan akan semakin kecil kontribusi SC dalam hal tersebut. Lebih lanjut Pulic menyatakan bahwa SC adalah VA dikurangi HC, yang hal ini telah diverifikasi melalui penelitian empiris pada sektor industri tradisional.

\section{STVA $=$ SC $/$ VA}

Keterangan:

SC = Structural Capital : VA - HC

$\mathrm{VA}=$ Value Added

Tahap Kelima : Menghitung Value Added Intellectual Coefficient (VAICTM)

VAICTM mengindikasikan kemampuan intelektual organisasi yang dapat juga dianggap sebagai BPI (Business Performance Indicator). VAICTM merupakan penjumlakan dari tiga komponen sebelumnya, yaitu: VACA, VAHU, dan STVA.

$$
\text { VAICTM }=\text { VACA + VAHU + STVA }
$$

\subsection{Variabel Intervening (Keunggulan Kompetitif)}

Dalam penelitian ini, keunggulan kompetitif (competitive advantage) digunakan sebagai variabel intervening. Variabel keunggulan kompetitif dapat diukur dengan menggunakan asset utilization capability, yaitu rasio pendapatan terhadap total asset yang mengukur seberapa efisien perusahaan menggunakan kepemilikan asetnya untuk 


\section{NATIONALLY ACCREDITED JOURNAL - DECREE NO. 21/E/KPT/2018}

menghasilkan pendapatan. Kariyoto (2016:45), menyebutkan jenis-jenis Asset Utilization Capability Ratio atau Rasio Pemanfaatan Aset yaitu: Rasio Perputaran Total Aset, Rasio Perputaran Modal Kerja, Rasio Perputaran Aset Tetap, dan Rasio Perbandingan Perputaran Aset Lain-Lain. Sehingga dalam buku Brigham dan Houston (2010:139), dapat dihitung rasio perputaran total asset (total asset turnover ratio) dengan mengukur perputaran seluruh asset perusahaan untuk menghasilkan pendapatan, dan dihitung dengan membagi penjualan/ penghasilan dengan total asset.

\section{Asset Utilization Capability $=\quad$ Sales (calculated by total asset turnover ratio) Total Asset}

\subsection{Variabel Terikat (Kinerja Keuangan)}

Rasio yang digunakan untuk mengukur kinerja keuangan perusahaan adalah Rasio EVA (Economic Value Added). Dipilihnya rasio ini dikarenakan EVA merupakan pengukuran kinerja keuangan yang dianggap sesuai dengan harapan investor karena EVA tidak hanya melihat dari tingkat pengembalian saham saja tetapi juga mempertimbangkan tingkat rasio perusahaan. Penerapan Economic Value Addded (EVA) dalam suatu perusahaan akan lebih memfokuskan perhatian pada penciptaan nilai perusahaan, hal ini merupakan salah satu keunggulan Economic Value Added (Poetri, 2013). Menurut Brigham dan Houston (2010:111) Economic Value Added dirumuskan sebagai berikut:

$E V A=$ NOPAT - biaya modal tahunan

$=$ EBIT $(1-T)-($ capital $\times$ cost of capital $)$

Dimana :

NOPAT = laba operasional bersih setelah pajak (Net Operational Profit After Tax)

EBIT = laba bersih sebelum bunga dan pajak (Earning Before Interest and Tax)

$\mathrm{T} \quad=$ tingkat pajak $($ Tax $)$

capital $=$ total modal operasi dari investor

cost of capital = prosentase biaya modal setelah pajak

Dalam penelitian ini, pengolahan data dilakukan dengan menggunakan analisis statistik deskriptif, analisis regresi, dan analisis jalur (path). Pengujian efek mediasi dilakukan dengan menggunakan Sobel Test untuk mengetahui ada tidaknya pengaruh tidak langsung. Perhitungan koefisien, standar eror, dan nilai t hitung pada pengaruh tidak langsung disajikan sebagai berikut:

$$
\mathbf{P}_{\mathrm{ab}}=\mathbf{P}_{\mathrm{a}^{2}} \mathbf{x} \mathbf{P}_{\mathrm{b}^{2}}
$$

$$
\begin{aligned}
& \mathbf{S}_{\mathrm{ab}}=\sqrt{\left(P \boldsymbol{a}^{2} x S b^{2}\right)+\left(P b^{2} x S b^{2}\right)+\left(S a^{2} x S b^{2}\right)} \\
& \mathbf{t}_{\mathrm{ab}}=\mathrm{P}_{\mathrm{ab}} / \mathrm{S}_{\mathrm{ab}}
\end{aligned}
$$

dimana $\mathrm{P}_{\mathrm{ab}}$ adalah koefisien pengaruh tidak langsung, $\mathrm{S}_{\mathrm{ab}}$ adalah standar eror pengaruh tidak langsung, dan $t_{a b}$ adalah nilai t-hitung pengaruh tidak langsung.

\section{HASIL DAN PEMBAHASAN}

\subsection{Hasil}

3.1.1. Pengaruh Modal Intelektual terhadap Keunggulan Kompetitif Perusahaan di Indonesia.

Model Summary ${ }^{b}$

\begin{tabular}{|l|r|r|r|r|}
\hline Model & R & R Square & Adjusted R Square & $\begin{array}{c}\text { Std. Error of the } \\
\text { Estimate }\end{array}$ \\
\hline 1 &, $337 \mathrm{a}$ &, 114 &, 104 &, 28153 \\
\hline
\end{tabular}

a. Predictors: (Constant), VAIC

jmm.unram.ac.id 


\section{NATIONALLY ACCREDITED JOURNAL - DECREE NO. 21/E/KPT/2018}

b. Dependent Variable: AUC

\begin{tabular}{|c|c|c|c|c|c|c|}
\hline \multicolumn{7}{|c|}{ ANOVA $^{\mathrm{a}}$} \\
\hline & & $\begin{array}{l}\text { Sum of } \\
\text { Squares }\end{array}$ & Df & Mean Square & $\mathrm{F}$ & Sig. \\
\hline \multirow{3}{*}{1} & Regression & ,985 & 1 & \multirow{3}{*}{$\begin{array}{l}\text {,985 } \\
\text {,079 }\end{array}$} & \multirow[t]{3}{*}{12,429} & \multirow[t]{3}{*}{, $001^{\mathrm{b}}$} \\
\hline & Residual & 7,688 & 97 & & & \\
\hline & Total & 8,673 & 98 & & & \\
\hline
\end{tabular}

a. Dependent Variable: AUC

b. Predictors: (Constant), VAIC

\section{Coefficients ${ }^{\mathrm{a}}$}

\begin{tabular}{|rr|r|r|r|r|r|}
\hline \multicolumn{2}{|l|}{ Model } & \multicolumn{2}{|c|}{ Unstandardized Coefficients } & $\begin{array}{c}\text { Standardized } \\
\text { Coefficients }\end{array}$ & \multirow{2}{*}{ T } & \multirow{2}{*}{ Sig. } \\
\cline { 2 - 5 } & B & Std. Error & Beta & & \\
\hline \multirow{2}{*}{1} & (Constant) &, 341 &, 117 & & 2,907 &, 005 \\
& VAIC &, 157 &, 045 &, 337 & 3,525 &, 001 \\
\hline
\end{tabular}

a. Dependent Variable: AUC

Hasil persamaan jalur dari persamaan 1 adalah sebagai berikut:

$$
\mathrm{M}=0,337 \mathrm{X}+\mathrm{e}
$$

Koefisien jalur pengaruh antara Modal Intelektual terhadap Keunggulan Kompetitif sebesar 0,337 yang menunjukkan semakin baik dan efisien pengelolaan Modal Intelektual, maka semakin baik Keunggulan Kompetitif perusahaan. Nilai signifikansi lebih kecil dari alpha 0,05 menunjukkan pengaruh Modal Intelektual terhadap Keunggulan Kompetitif adalah berpengaruh signifikan. Nilai R square sebesar 0,114 menunjukkan besar pengaruh terhadap Keunggulan Kompetitif yang disebabkan oleh Modal Intelektual adalah sebesar $11,4 \%$, sedangkan $88,6 \%$ pengaruh terhadap Keunggulan Kompetitif disebabkan oleh variabel lain.

\subsubsection{Pengaruh Modal Intelektual terhadap Kinerja Keuangan Perusahaan dan pengaruh Keunggulan Kompetitif terhadap Kinerja Keuangan Perusahaan di Indonesia}

Model Summaryb

\begin{tabular}{|l|r|r|r|r|}
\hline Model & R & R Square & Adjusted R Square & \multicolumn{1}{|c|}{$\begin{array}{c}\text { Std. Error of the } \\
\text { Estimate }\end{array}$} \\
\hline 1 &, $520^{\mathrm{a}}$ &, 271 &, 256 &, 03903 \\
\hline
\end{tabular}

a. Predictors: (Constant), AUC, VAIC

b. Dependent Variable: EVA

ANOVAa

\begin{tabular}{|rl|r|r|r|r|r|}
\hline Model & \multicolumn{1}{|c|}{$\begin{array}{c}\text { Sum of } \\
\text { Squares }\end{array}$} & Df & Mean Square & F & Sig. \\
\hline \multirow{2}{*}{1} & Regression &, 054 & 2 &, 027 & 17,819 &, $000^{\mathrm{b}}$ \\
& Residual &, 146 & 96 &, 002 & & \\
& Total &, 201 & 98 & & & \\
\hline
\end{tabular}

a. Dependent Variable: EVA

b. Predictors: (Constant), AUC, VAIC 
Coefficients

\begin{tabular}{|c|c|c|c|c|c|c|}
\hline \multirow{2}{*}{\multicolumn{2}{|c|}{ Model }} & \multicolumn{2}{|c|}{ Unstandardized Coefficients } & \multirow{2}{*}{$\begin{array}{c}\text { Standardized } \\
\text { Coefficients } \\
\text { Beta }\end{array}$} & \multirow[t]{2}{*}{$\mathrm{T}$} & \multirow[t]{2}{*}{ Sig. } \\
\hline & & B & Std. Error & & & \\
\hline \multirow{3}{*}{1} & (Constant) & ,030 & , 017 & & 1,746 & ,084 \\
\hline & VAIC & 016 & 007 & 219 & 2,367 & , 020 \\
\hline & AUC & ,061 & ,014 & ,404 & 4,362 & ,000 \\
\hline
\end{tabular}

a. Dependent Variable: EVA

Hasil persamaan jalur II adalah sebagai berikut:

$$
\mathrm{Y}=0,219 \mathrm{X}+0,404 \mathrm{M}+\mathrm{e}
$$

Koefisien jalur pengaruh Modal Intelektual terhadap Kinerja Keuangan Perusahaan sebesar 0,219 menunjukkan semakin baik dan efisien pengelolaan Modal Intelektual, maka semakin tinggi Kinerja Keuangan perusahaan. Kemudian koefisien jalur pengaruh Keunggulan Kompetitif terhadap Kinerja Keuangan Perusahaan sebesar 0,404 menunjukkan pengaruh positif atau berbanding lurus, artinya semakin baik Keunggulan Kompetitif, maka semakin tinggi Kinerja Keuangan perusahaan. Nilai signifikansi masingmasing pengaruh lebih kecil dari alpha 0,05 yang menunjukkan pengaruh Modal Intelektual terhadap Kinerja Keuangan Perusahaan dan pengaruh Keunggulan Kompetitif terhadap Kinerja Keuangan Perusahaan adalah berpengaruh signifikan. Nilai R square sebesar 0,271 menunjukkan besar pengaruh terhadap Kinerja Keuangan perusahaan yang disebabkan oleh Modal Intelektual dan Keunggulan Kompetitif adalah sebesar 27,1\%, sedangkan $72,9 \%$ pengaruh terhadap Kinerja Keuangan perusahaan disebabkan oleh variabel lain.

\subsubsection{Pengaruh Modal Intelektual terhadap Kinerja Keuangan Perusahaan melalui} Keunggulan Kompetitif Perusahaan di Indonesia

Berdasarkan hasil perhitungan didapatkan koefisien pengaruh Modal Intelektual terhadap Kinerja Keuangan Perusahaan melalui Keunggulan Kompetitif sebesar 0,1362 yang menunjukkan pengaruh positif atau berbanding lurus, artinya semakin efisien pengelolaan Modal Intelektual maka semakin tinggi Kinerja Keuangan perusahaan.

Nilai t hitung pengaruh Modal Intelektual terhadap Kinerja Keuangan Perusahaan melalui Keunggulan Kompetitif sebesar 7,2447 menunjukkan model pengaruh tidak langsung adalah berpengaruh signifikan pada alpha 0,05.

3.1.4. Pengujian pengaruh langsung antara variabel bebas dan variabel mediasi, yaitu pengaruh Modal Intelektual terhadap Keunggulan Kompetitif Perusahaan di Singapura.

Model Summary ${ }^{b}$

\begin{tabular}{|l|r|r|r|r|}
\hline Model & R & R Square & Adjusted R Square & $\begin{array}{c}\text { Std. Error of the } \\
\text { Estimate }\end{array}$ \\
\hline 1 &, $550^{\mathrm{a}}$ &, 302 &, 293 &, 24516 \\
\hline
\end{tabular}

a. Predictors: (Constant), VAIC

b. Dependent Variable: AUC 
ANOVAa

\begin{tabular}{|rl|r|r|r|r|r|}
\hline Model & \multicolumn{1}{|c|}{$\begin{array}{c}\text { Sum of } \\
\text { Squares }\end{array}$} & Df & Mean Square & F & Sig. \\
\hline \multirow{2}{*}{1} & Regression & 1,979 & 1 & 1,979 & 32,925 &, $000^{\mathrm{b}}$ \\
& Residual & 4,568 & 76 &, 060 & & \\
& Total & 6,547 & 77 & & & \\
\hline
\end{tabular}

a. Dependent Variable: AUC

b. Predictors: (Constant), VAIC

Coefficients ${ }^{a}$

\begin{tabular}{|c|c|c|c|c|c|}
\hline \multirow[t]{2}{*}{ Model } & \multicolumn{2}{|c|}{ Unstandardized Coefficients } & & \multirow[t]{2}{*}{$\mathrm{T}$} & \multirow[t]{2}{*}{ Sig. } \\
\hline & B & Std. Error & Beta & & \\
\hline $\begin{array}{ll}1 & \text { (Constant) } \\
\text { VAIC }\end{array}$ & , 067 & $\begin{array}{l}, 074 \\
, 028\end{array}$ & ,55 & $\begin{array}{r}, 904 \\
5,738\end{array}$ & $\begin{array}{l}369 \\
, 000\end{array}$ \\
\hline
\end{tabular}

a. Dependent Variable: AUC

Hasil persamaan jalur dari persamaan 1 adalah sebagai berikut:

$$
\mathrm{M}=0,55 \mathrm{X}+\mathrm{e}
$$

Koefisien jalur pengaruh antara Modal Intelektual terhadap Keunggulan Kompetitif sebesar 0,55 yang menunjukkan pengaruh positif atau berbanding lurus, artinya semakin baik dan efisien pengelolaan Modal Intelektual, maka semakin baik Keunggulan Kompetitif perusahaan. Nilai signifikansi lebih kecil dari alpha 0,05 menunjukkan pengaruh Modal Intelektual terhadap Keunggulan Kompetitif adalah berpengaruh signifikan. Nilai R square sebesar 0,302 menunjukkan besar pengaruh terhadap Keunggulan Kompetitif yang disebabkan oleh Modal Intelektual adalah sebesar 30,2\%, sedangkan 69,8\% pengaruh terhadap Keunggulan Kompetitif disebabkan oleh variabel lain.

3.1.5. Pengujian pengaruh Modal Intelektual terhadap Kinerja Keuangan Perusahaan dan pengaruh Keunggulan Kompetitif terhadap Kinerja Keuangan Perusahaan di Singapura.

Model Summaryb

\begin{tabular}{|l|r|r|r|r|}
\hline Model & \multicolumn{1}{|c|}{$\mathrm{R}$} & R Square & Adjusted R Square & $\begin{array}{c}\text { Std. Error of the } \\
\text { Estimate }\end{array}$ \\
\hline 1 &, $514^{\mathrm{a}}$ &, 265 &, 245 &, 05898 \\
\hline
\end{tabular}

a. Predictors: (Constant), AUC, VAIC

b. Dependent Variable: EVA

ANOVA $^{a}$

\begin{tabular}{|rl|r|r|r|r|r|}
\hline Model & Sum of Squares & Df & Mean Square & F & Sig. \\
\hline \multirow{4}{*}{1} & Regression &, 094 & 2 &, 047 & 13,488 &, $000^{\mathrm{b}}$ \\
& Residual &, 261 & 75 &, 003 & & \\
& Total &, 355 & 77 & & & \\
\hline
\end{tabular}

a. Dependent Variable: EVA

b. Predictors: (Constant), AUC, VAIC 
Coefficients

\begin{tabular}{|c|c|c|c|c|c|c|}
\hline \multirow{2}{*}{\multicolumn{2}{|c|}{ Model }} & \multicolumn{2}{|c|}{ Unstandardized Coefficients } & \multirow{2}{*}{$\begin{array}{c}\text { Standardized } \\
\text { Coefficients } \\
\text { Beta }\end{array}$} & \multirow[t]{2}{*}{$\mathrm{T}$} & \multirow[t]{2}{*}{ Sig. } \\
\hline & & B & Std. Error & & & \\
\hline \multirow{3}{*}{1} & (Constant) & ,053 & , 018 & & 2,952 & ,004 \\
\hline & VAIC & ,022 & 008 & 329 & 2,779 & 007 \\
\hline & AUC & ,059 & ,028 & 253 & 2,137 & ,036 \\
\hline
\end{tabular}

a. Dependent Variable: EVA

Hasil pengaruh Modal Intelektual terhadap Kinerja Keuangan Perusahaan dan pengaruh Keunggulan Kompetitif terhadap Kinerja Keuangan Perusahaan adalah sebagai berikut:

$$
\mathrm{Y}=0,329 \mathrm{X}+0,253 \mathrm{M}+\mathrm{e}
$$

Koefisien jalur pengaruh Modal Intelektual terhadap Kinerja Keuangan Perusahaan sebesar 0,329 menunjukkan semakin baik dan efisien pengelolaan Modal Intelektual, maka semakin tinggi Kinerja Keuangan perusahaan. Kemudian koefisien jalur pengaruh Keunggulan Kompetitif terhadap Kinerja Keuangan Perusahaan sebesar 0,253 menunjukkan semakin baik Keunggulan Kompetitif, maka semakin tinggi Kinerja Keuangan perusahaan. Nilai signifikansi masing-masing pengaruh lebih kecil dari alpha 0,05 yang menunjukkan pengaruh Modal Intelektual terhadap Kinerja Keuangan Perusahaan dan pengaruh Keunggulan Kompetitif terhadap Kinerja Keuangan Perusahaan adalah berpengaruh signifikan.

Nilai R square sebesar 0,265 menunjukkan besar pengaruh terhadap Kinerja Keuangan perusahaan yang disebabkan oleh Modal Intelektual dan Keunggulan Kompetitif adalah sebesar 26,5\%, sedangkan 73,5\% pengaruh terhadap Kinerja Keuangan perusahaan disebabkan oleh variabel lain. Berdasarkan hasil perhitungan didapatkan koefisien pengaruh Modal Intelektual terhadap Kinerja Keuangan Perusahaan melalui Keunggulan Kompetitif sebesar 0,13915 yang menunjukkan pengaruh positif atau berbanding lurus, artinya semakin efisien pengelolaan Modal Intelektual maka semakin tinggi Kinerja Keuangan perusahaan. Nilai $t$ hitung pengaruh Modal Intelektual terhadap Kinerja Keuangan Perusahaan melalui Keunggulan Kompetitif sebesar 8,1998 menunjukkan model pengaruh tidak langsung adalah berpengaruh signifikan pada alpha 0,05 .

\subsubsection{Pengaruh Modal Intelektual terhadap Kinerja Keuangan Perusahaan melalui Keunggulan Kompetitif Perusahaan di Singapura}

Berdasarkan hasil perhitungan didapatkan koefisien pengaruh Modal Intelektual terhadap Kinerja Keuangan Perusahaan melalui Keunggulan Kompetitif sebesar 0,13915 yang menunjukkan pengaruh positif atau berbanding lurus, artinya semakin efisien pengelolaan Modal Intelektual maka semakin tinggi Kinerja Keuangan perusahaan.

Nilai t hitung pengaruh Modal Intelektual terhadap Kinerja Keuangan Perusahaan melalui Keunggulan Kompetitif sebesar 8,1998 menunjukkan model pengaruh tidak langsung adalah berpengaruh signifikan pada alpha 0,05.

\subsection{Pembahasan Hasil Penelitian}

3.2.1. Modal Intelektual (Intellectual Capital) berpengaruh positif signifikan terhadap Kinerja Keuangan dan Keunggulan Kompetitif perusahaan

Berdasarkan hasil analisis statistik, Modal Intelektual berpengaruh positif dan signifikan terhadap Kinerja Keuangan perusahaan di Indonesia maupun Singapura. 
Artinya, bahwa perusahaan yang mampu mengelola modal intelektual yang dimiliki manusia dalam perusahaan dengan baik, maka perusahaan tersebut akan dapat menciptakan value added sehingga kinerja keuangan perusahaan meningkat. Hasil penelitian ini mendukung teori modal intelektual menurut Thomas A. Stewart (1997:1) bahwa modal intelektual merupakan kumpulan manusia dalam perusahaan yang dapat memberikan aspek kompetitif perusahaan dalam posisi pasar. Aspek kompetitif yang menjadi pembeda perusahaan dengan saingannya adalah intelektualitas, ilmu pengetahuan yang dimiliki, pengelolaan informasi, hak paten intelektual, dan pengalaman yang dapat digunakan untuk menciptakan kesejahteraan (kinerja) perusahaan.

Hasil penelitian ini juga mendukung pernyataan Ulum (2009:6) tentang pengelolaan modal intelektual dalam teori stakeholoder, bahwa perusahaan merupakan kumpulan manusia yang memiliki intelektualitas untuk dikelola bersama dalam mencapai tujuan, bukan semata entitas yang hanya beroperasi untuk kepentingan pribadi, namun harus memberikan manfaat bagi stakeholdernya. Stakeholder berwenang untuk mempengaruhi manajemen dalam proses pemanfaatan seluruh potensi yang dimiliki organisasi untuk pengelolaan yang baik dan maksimal agar dapat menciptakan value added untuk kemudian mendorong kinerja keuangan perusahaan. Stewart (1997:2), bahwa pengaruh terhadap kinerja keuangan perusahaan ini merupakan hasil dari pengelolaan atas intelektualitas/ ilmu pengetahuan yang dimiliki, informasi, hak paten intelektual, dan pengalamanpengalaman kerja sebagai ilmu yang berharga dan berbeda setiap individunya.

Prosentase pengaruh yang diberikan modal intelektual terhadap kinerja keuangan perusahaan di Indonesia lebih besar daripada di Singapura, karena seperti yang kita ketahui bahwa peningkatan kinerja di Singapura tidak hanya dipengaruhi oleh kemampuan pengelolan sumber daya manusia saja, menurut Pricewaterhouse Coopers (PwC, 2014) mengukur indikator keberhasilan dari kemudahan melakukan usaha atau ease of doing business, demografi, dan kesiapan teknologi. Hasil dari penelitian ini mendukung penelitian Lestari (2012), Poetri (2013), Dwipayani (2014), Najah (2014), Daud (2016), Devi dkk (2017), dan Garanina (2017) yang menyatakan bahwa Modal Intelektual berpengaruh terhadap Kinerja Keuangan Perusahaan dengan proksi variabel yang berbeda pada masing-masing penelitian.

Berdasarkan hasil analisis statistik, Modal Intelektual berpengaruh positif dan signifikan terhadap Keunggulan Kompetitif masing-masing perusahaan di Indonesia dan Singapura. Artinya, perusahaan yang memiliki kemampuan pengelolaan modal intelektual yang baik akan memiliki diferensiasi dari perusahaan saingan, yaitu keunggulan kompetitif sebagai nilai plus perusahaan dalam bersaing di pasar, seperti yang dinyatakan Stewart (1997:2) bahwa aspek kompetitif yang menjadi pembeda perusahaan dengan saingannya adalah intelektualitas, ilmu pengetahuan yang dimiliki, pengelolaan informasi, hak paten intelektual, dan pengalaman yang dapat digunakan untuk menciptakan kesejahteraan perusahaan. Penelitian ini mendukung teori Keunggulan kompetitif yang disebutkan Barney dan Clark (2007) dalam Resource Based Theory (RBT) bahwa perusahaan tidak dapat membeli atau mengambil keunggulan kompetitif yang dimiliki perusahaan lain, karena keunggulan tersebut merupakan sumber daya yang langka, sukar ditiru, dan tidak tergantikan. Untuk menciptakan dan mempertahankan keunggulan kompetitif, Susanto (2014: 83-84) menyebutkan dengan cara mengembangkan keterampilan, sumber daya, dan proses pengelolaan yang dapat meningkatkan nilai (value) bagi pelanggan. Teori RBT ini menekankan bahwa perspektif strategik dari perusahaan hanya tergantung pada adanya sumber daya internal, aset, kapabilitas, dan kompetisi guna mencapai keunggulan kompetitif, yaitu berupa modal intelektual.

Hasil penelitian ini mendukung hasil penelitian Widyaningdyah (2013) yang menyatakan bahwa modal intelektual dapat digunakan untuk menciptakan dan 
menggunakan pengetahuan untuk meningkatkan nilai perusahaan. Suwarjuwono dan Kadir (2003) menyatakan bahwa perusahaan-perusahaan di Indonesia akan dapat bersaing apabila menggunakan keunggulan kompetitif yang diperoleh melalui inovasi-inovasi kreatif yang dihasilkan oleh modal intelektual perusahaan. Begitu pula Sudiarditha (2005), bila fungsi manajemen sumberdaya manusia berjalan sendiri-sendiri dan tidak senantiasa dikaitkan dengan visi, tujuan, dan strateginya maka perusahaan akan mengalami kesulitan untuk mendapatkan keunggulan kompetitif (competitive advantage). Dengan kata lain, semakin baik perusahaan mengelola modal intelektual yang dimiliki, maka akan tercipta keunggulan kompetitif, sebagai kekuatan bersaing perusahaan di era pasar global.

\subsubsection{Keunggulan Kompetitif (competitive advantage) berpengaruh positif signifikan terhadap Kinerja Keuangan Perusahaan.}

Berdasarkan hasil analisis statistik, pengaruh Keunggulan Kompetitif terhadap Kinerja Keuangan Perusahaan Indonesia dan Singapura, masing-masing menunjukkan hasil yang positif dan signifikan. Artinya, jika perusahaan memiliki kemampuang bersaing atau memiliki posisi pasar, perusahaan dapat meningkatkan kinerja keuangan perusahaan, seperti yang dikatakan David (2011:9), keunggulan kompetitif merupakan hal apapun yang dapat dilakukan perusahaan sehingga lebih baik dibandingkan dengan perusahaan saingan.

Hasil penelitian ini mendukung hasil penelitian Widyaningdyah dan Aryani (2013), bahwa sebuah perusahaan dikatakan mempunyai keunggulan kompetitif apabila dapat menciptakan nilai ekonomis yang lebih tinggi dibandingkan perusahaan lain dalam industrinya. Sehingga berakibat pada peningkatan kinerja keuangan perusahaan. Potensi ini disebutkan dalam riset PKRB (2014) bahwa Indonesia memiiki jumlah penduduk Indonesia yang besar sebagai bonus demografi yang dapat menjadi kunci sukses bagi peningkatan daya saing Indonesia. Dengan dukungan peningkatan pendidikan dan ketrampilan, maka produktivitas tenaga kerja akan meningkat. Peningkatan produktivitas tenaga kerja ini pada akhirnya mendorong peningkatan daya saing nasional. Perusahaan yang mampu mengelola sumberdaya intelektualnya diyakini mampu menciptakan value added serta mampu menciptakan keunggulan kompetitif dengan melakukan inovasi, penelitian dan pengembangan yang akan bermuara terhadap peningkatan kinerja keuangan perusahaan (Ulum, 2009:111).

3.2.3. Terdapat pengaruh poisitif signifikan antara Modal Intelektual (Intellectual Capital) terhadap Kinerja Keuangan Perusahaan melalui Variable Keunggulan Kompetitif (Competitive Advantage).

Berdasarkan hasil analisis statistik, Modal Intelektual terhadap Kinerja Keuangan Perusahaan melalui Keunggulan Kompetitif berpengaruh positif dan signifikan pada perusahaan Indonesia dan Singapura. Artinya, perusahaan yang mampu mengelola modal intelektual dengan baik, akan mampu menciptakan keunggulan kompetitif berupa diferensiasi atas perusahaan saingan sehingga mampu meningkatkan kinerja keuangan perusahaan dan memiliki posisi bersaing yang kuat

Hasil penelitian ini mendukung teori stakeholder yang menyatakan bahwa jika seluruh potensi yang dimiliki organisasi dimanfaatkan dengan baik dan maksimal maka perusahaan akan mampu menciptakan value added untuk kemudian mendorong kinerja keuangan perusahaan sebagai bentuk intervensi stakeholder dalam manajemen (Ulum 2007:6). Sejalan dengan pendekatan berbasis sumber daya (resource-based view of the firm theory/ RBT), teori ini dikembangkan untuk menganalisis keunggulan bersaing suatu perusahaan yang menonjolkan keunggulan pengetahuan atau perekonomian yang mengandalkan aset-aset tak berwujud. 


\section{NATIONALLY ACCREDITED JOURNAL - DECREE NO. 21/E/KPT/2018}

Kumpulan sumber daya yang unik yang dimiliki dan dikendalikan perusahaan memungkinkan perusahaan untuk mencapai dan mempertahankan kinerja superior yang berkelanjutan. Sumber daya unik yang dimaksudkan dalam RBT adalah sumber daya yang bernilai (valuable), langka (rare), tidak dapat ditiru (inimitable), dan tidak tergantikan (nonsubtitutable). Jenis sumber daya ini dapat mengantarkan perusahaan pada pencapaian keunggulan kompetitif (Widyaningdyah dan Aryani, 2013). Modal intelektual merupakan sumberdaya yang terukur untuk peningkatan keunggulan kompetitif, maka modal intelektual akan memberikan kontribusi terhadap kinerja keuangan perusahaan (Ulum, 2009:94).

Penelitian atas pengaruh tak langsung ini mendukung penelitian Pratama (2015), Libyanita dan Wahidahwati (2016), dan Indah (2017) yang secara umum menyimpulkan bahwa modal intelektual berpengaruh terhadap kinerja keuangan perusahaan melalui keunggulan kompetitif dalam perusahaan dengan indikator dan pengukuran serta metode analisis yang berbeda-beda sesuai dengan keadaan peneliti.

\section{KESIMPULAN}

4.1. Terdapat pengaruh positif dan signifikan modal intelektual (intellectual capital) terhadap inerja keuangan perusahaan dan keuanggulan kompetitif, di Indonesia dan Singapura.

4.2. Terdapat pengaruh positif dan signifikan keunggulan kompetitif (competitive advantage) terhadap kinerja keuangan perusahaan, di Indonesia dan Singapura.

4.3. Terdapat pengaruh positif dan signifikan modal intelektual (Intellectual Capital) terhadap kinerja keuangan perusahaan melalui keunggulan kompetitif (Competitive Advantage) sebagai variable intervening.

\section{SARAN}

5.1. Peneliti selanjutnya sebaiknya menggunakan rentang tahun yang lebih banyak dan menambah proksi pengukuran kinerja perusahaan serta model pengukuran modal intelektual capital lainnya, sehingga dapat memberikan wawasan lebih luas pengaruh modal intelektual terhadap kinerja perusahaan.

5.2. Bagi lembaga yang terkait untuk dapat menetapkan standar mengenai penyajian dan pengungkapan modal intelektual dan menambahkan rasio economic value added seperti laporan keuangan di Negara Singapura, sehingga dalam laporan keuangan dapat menjadikan salah satu pentingnya modal intelektual dalam proses penciptaan nilai tambah untuk meningkatkan kinerja keuangan perusahaan di era Knowledge Based Economy saat ini.

\section{DAFTAR PUSTAKA}

Barney, J.B. dan Clark, D.N. (2007). Resource Based Theory: Creating and Sustaining Competitive Advantage. New York: Oxford University Press, Inc.

Brigham, Eugene F. dan Houston, Joel F. (2010). Dasar-dasar Manajemen Keuangan, Essentials of Financial Management. Jakarta: Penerbit Salemba Empat.

Centre of Knowledge for Business Competitiveness (CK4BC). (2015). Peran Penting

Knowledge Management Dalam Mewujudkan Ekonomi Berbasis Pengetahuan. ResearchGate.

M\&E, Vol. 13, No. 1, Maret 2015. Diperoleh tanggal 4 Januari 2018 dari

https://www.researchgate.net/publication/315736318. 


\section{NATIONALLY ACCREDITED JOURNAL - DECREE NO. 21/E/KPT/2018}

Daud, Robert Mario. (2016), Pengaruh Intellectual Capital Terhadap Kinerja Keuangan Perusahaan dan Return Saham, Skripsi. Fakultas Ekonomi Dan Bisnis Universitas Lampung, Bandar Lampung.

David, F. R. (2011). Strategic Management: Concepts and Cases (13 thed.). New Jersey: Prentice Hall.

Deny, Septian. (14 Desember 2016). Ini Sebab Singapura Bisa Lebih Maju dari Indonesia. Liputan6.com. Diperoleh tanggal 12 Oktober dari http:/ / bisnis.liputan6.com/read/2677613/ini-sebab-singapura-bisa-lebih-maju-dariindonesia.

Dessler, Gary. (2001). Human Resource Management. Eight Edition. Prentice Hall International Inc.

Devi, Bunga Ekawati., Khairunnisa, dan Budiono, Eddy. (2017). The Influence of Intellectual Capital on the Company Financial Performance. Jurnal Akuntansi. Vol. 3 No. 2.Januari 2017.

Dwipayani, Chrisnatty Chandra. (2014), Pengaruh Intellectual Capital Terhadap Profitabilitas dan Kinerja Pasar.Skripsi (tidak dipublikasikan). Fakultas Ekonomika Dan Bisnis Universitas Diponegoro, Semarang.

Garanina, Tatiana. (2017). Intellectual Capital and Its Impact on the Financial Performance of Russian Manufacturing Companies.Foresight And Sti Governance 2017 Vol. 11 No 1.

Global Competitiveness Index. (2016). Diaskes pada 11 Oktober 2017 dari http:/ / reports.weforum.org/global-competitiveness-index-2017-2018/

Hartati, Noorina (2014). Intellectual Capital Dalam Meningkatkan Daya Saing: Sebuah Telaah Literatur. Jurnal Etikonomi Vol. 13 No. 1 April 2014. Oktober 2017.

https://valueinvestingsingapore.sg/sti-index-singapore/, diakses tanggal 11

http://www.idx.com/, diakses tanggal 1 Oktober 2017.

http:/ / www.sgx.com/, diaksestanggal 11 Oktober 2017.

Indah, Dewi Yuliati. (2017). Pengaruh Modal Intelektual Terhadap Keunggulan Bersaing Serta Implikasinya Pada Kinerja Organisasi (Survey pada Perusahaan UKM Bidang Produk Kreatif di Provinsi Jawa Barat).

International Federation of Accountants. 1998, The Measurement and Management of Intellectual capital: An Introduction. New York.

Kariyoto. (2016). Analisis Laporan Keuangan. Malang: UB Press.

Kemendag, (2015). Perkembangan Ekspor NonMigas (Komoditi) Periode : 20092014, http://www.kemendag.go.id/id/economicprofile/indonesia-export-import/growth-ofnon-oil-andgas-export-commodity, diakses 2 Januari 2018.

Lestari, Santi Dwie. (2012). Pengaruh Intellectual Capital Terhadap Kinerja Keuangan Perbankan Syari' ah Di Indonesia.Ekuitas: Jurnal Ekonomi dan Keuangan ISSN 1411 - 0393 Akreditasi No. 80/DIKTI/Kep/2012.

Libyanita, Mayangtari dan Wahidahwati.(2016). Pengaruh Intellectual Capital Terhadap Kinerja Keuangan dengan Competitive Advantage sebagai Variabel Intervening.Jurnal Ilmu dan Riset Akuntansi : Volume 5, Nomor 6, Juni 2016.

Najah, Anisa Nurun. (2014). Pengaruh Intellectual Capital dan Tata Kelola Perusahaan Terhadap Kinerja Keuangan pada Perusahaan yang Masuk Daftar Efek Syariah (DES) per. 2010-2012, Skripsi. Fakultas Ekonomika Dan Bisnis Universitas Diponegoro, Semarang.

PKRB. (2014). Analisa Daya Saing dan Produktivitas Indonesia Menghadapi MEA. Diakses pada 15 Januari 2018 dari https://www.kemenkeu.go.id/ 


\section{NATIONALLY ACCREDITED JOURNAL - DECREE NO. 21/E/KPT/2018}

sites/default/files/kajian \%20daya \%20saing\%20dan\%20produktivitas\%20indonesia \%20me nghadapi \%20mea.pdf.

Poetri, Fika Shelviana Restu. (2013), Pengaruh Intellectual Capital Terhadap Economic Value Added (EVA) pada Perusahaan Perbankan yang Terdaftar di BEI periode 2011-2013.Journal of Intellectual Capital, 12(1), 152-164.

Porter, M. E. (1985). Competitive Advantage: Creating and Sustaining Superior Performance (1sted). New York: Free Press.

Pratama, Yanto Hans. (2015), Pengaruh Intellectual Capital Terhadap Kinerja Perusahaan dengan Competitive Advantage sebagai Variabel Intervening, Skripsi. Fakultas Ekonomika Dan Bisnis Universitas Diponegoro, Semarang.

Pulic, Ante. (2000). VAIC - an accounting tool for IC management. Diperoleh pada tanggal 9 November 2017 dari www.vaic-on.net.

Pulic, Ante. (2008). The Principles of Intellectual Capital Efficiency - A Brief Description. Croatian Intellectual Capital Centre. Diperoleh tanggal 7 Oktober 2017 dari https:/ / www.google.co.id/ search?q=pulic+VAIC \&oq=pulic+VAIC\&aqs=chrome.

Riaupos.co. (2016). Intellectual Capital Solusi Atasi Perlambatan Ekonomi Global.www.riaupos.co. Diperoleh tanggal 23 Agustus 2017 dari http://www.riaupos.co/4854-opini-intellectual-capital-solusi-atasi-perlambatanekonomiglobal.html\#.WZz0wlUjHMy.

Stewart, Thomas A. (1997). Intellectual Capital: The New Wealth of Organizations. London: Nicholas Brealey Publishing.

Sudiarditha, I Ketut R. (2005).Pengaruh Intellectual Capital terhadap Keunggulan Bersaing.HUMANIORA Vol.3 No. 2 September 2005.

Susanto, AB. (2014). Manajemen Strategik Kmprehensif untuk Mahasiswa dan Praktisi. Jakarta: Penerbit Erlangga.

Suwarjuwono, T. dan Kadir, A.P. (2003). Intellectual Capital: Perlakuan, Pengukuran, dan Pelaporan (sebuah library research). Jurnal Akuntansi dan Keuangan.Vol. 5 No. 1 hal.35-37.

Tambun, Sihar (2014). Pengaruh Competitive Strategy Terhadap Kinerja Perusahaan Yang Dimoderasi Oleh Kepemilikan Manajerial Dan Kepemilikan Institusional Di Perusahaan Manufaktur Yang Terdaftar Di Bei. Seminar Nasional Kewirausahaan dan Inovasi Bisnis IV 2014, Universitas Tarumanagara, Jakarta, 8 Mei 2014, ISSN No: 2089-1040

Tan, H.P., D. Plowman, dan P. Hancock. (2007). Intellectual Capital and Financial Returns of Companies.Journal of Intellectual Capitlal.Vol. 8 No. 1 hal.76-95.

Tewal, Bernhard. (2012). Pengaruh Strategi Bersaing dan Inovasi Terhadap Kinerja Perusahaan Perhotelan di Sulawesi Utara. Jurnal Aplikasi Manajemen Vol. 8 No. 2 tahun 2010

Ulum, Ihyaul. (2009). Intellectual Capital, Konsep dan Kajian Empiris. Yogyakarta: Graha Ilmu.

Ulum, Ihyaul. (2008). Intellectual Capital Performance Sektor Perbankan di Indonesiall. Jurnal Akuntansi dan Keuangan. Vol. 10 (2): hal. 77-84.

Ulum, Ihyaul., Ghozali, Imam., dan Chariri, Anis. (2008). Intellectual Capital dan Kinerja Keuangan Perusahaan: Suatu Analisis dengan Pendekatan Partial Least Square. (Online). Diperoleh tanggal 15 Agustus 2017 dari http://eprints. undip.ac.id/17126/1/SNA11Ulum.

Widyaningdyah, Agnes Utari dan Aryani, Y. Anni.(2013), Intellectual Capital dan Keunggulan Kompetitif (Studi Empiris pada Perusahaan Manufaktur versi JASICA).Jurnal Akuntansi dan Keuangan, Vol. 15, No. 1, Mei 2013, 1-14. 